\title{
Is it expensive to be poor? Public transport in Sweden
}

\author{
Anders Bondemark ${ }^{1,2,3}$ (D) Henrik Andersson ${ }^{4} \cdot$ Anders Wretstrand $^{2,3}$. \\ Karin Brundell-Freij ${ }^{2,3,5}$
}

Published online: 23 October 2020

(c) The Author(s) 2020

\begin{abstract}
One of the reasons to subsidise public transport is to improve the mobility of low-income groups by providing affordable public transport; however, the literature describes a situation whereby those with a low income are unable to afford the cheapest tickets per trip, i.e. travelcards, as they usually require a considerable up-front cost. In this study, we use a large dataset from the Swedish National Travel Survey to investigate whether, and if so how, income explains monthly travelcard possession among individuals for whom this would have been the least expensive option. We find a robust positive relationship between income and travelcard possession among low-income earners, indicating that those with a low income pay more to use public transport than more affluent individuals. As the accessibility of low-income groups is an important motivation for public transport subsidies, the findings from this study have important policy implications.
\end{abstract}

Keywords Fares $\cdot$ Public transport $\cdot$ Income $\cdot$ Liquidity constraints

JEL Classification R48 $\cdot \mathrm{H} 41 \cdot \mathrm{D} 12$

\section{Introduction}

The Economist (2015) and The Brookings Institution (2006) both report that, in many cases, it is expensive to be poor. Whether it is financial services or mobile phone subscriptions, low-income earners face higher prices than those with higher incomes. This phenomenon is not, however, limited to the examples above; it has also been reported in the context of public transport (Jones and Lucas 2012).

Anders Bondemark

Anders.bondemark@vti.se

1 The Swedish National Road and Transport Institute (VTI), Postal address: VTI, Box 55685, 10215 Stockholm, Sweden

2 Lund University, Transport and Roads, Lund, Sweden

3 The Swedish Knowledge Centre for Public Transport, Lund, Sweden

4 Toulouse School of Economics, University of Toulouse Capitole, Toulouse, France

5 WSP Advisory, Malmö, Sweden 
Aside from the strictly economic motives for subsidising public transport-such as economies of scale (Mohring 1972; Jansson 1979; Else 1985; Basso and Jara-Diaz 2010; Börjesson et al. 2017) and second-best pricing of externalities (Proost and van Dender 2008; Parry and Small 2009; Parry and Timilsina 2010)—social motives, such as providing accessibility for and improving the mobility of low-income earners more reliant on public transport (Glaeser et al. 2008) may be just as important to public transport authorities. For instance, an important policy objective for the public transport systems in London (Mayor of London 2018), Berlin (Senate Department for the Environment, Transport and Climate Protection 2018), New York (New York City Department of Transportation 2016), Los Angeles (Los Angeles Department of City Planning 2016), Vancouver (City of Vancouver 2012) and Chicago (Regional Transportation Authority 2017) is to provide equitable and affordable public transport to the inhabitants of their respective cities. The Swedish public transport sector is no exception and for over half a century has sought to provide accessibility to those unable to afford, or in other ways, access a car (Ljungberg 2013). A concept commonly used to assess the mobility of low-income earners is the affordability of public transport systems (Serebrinsky et al. 2009; Gómez-Lobo 2011; Bocarejo and Oviedo 2012; Falavigna and Hernandez 2016; Guzman and Oviedo 2018). In this context, affordability (in various forms) is sometimes used to study the relationship between the cost of travel and social exclusion (Lucas 2011; El-Geneidy et al. 2016; Falavigna and Hernandez 2016). While we in this study, does not study social exclusion as a concept explicitly, we focus on a specific aspect related to affordability and social exclusion, i.e., public transport fare policies.

Fares are structured in different ways-flat, distance travelled, peak/off-peak, mode of transport-and/or discounted based on passenger characteristics (Brown 2018) and may therefore have different distributional effects depending on both fares and the structure of the region (Farber et al. 2014). Fares do however tend to be designed to encourage individuals to commit to using public transport in order to realise the positive externalities (i.e. the Mohring effect ${ }^{1}$ ), to reduce the negative ones and to achieve a predictable level of demand. This translates into higher subsidies for travelcards with longer periods of validity, which require a higher up-front payment than single tickets or travelcards with a shorter period of validity. Thus, the least expensive option per trip for frequent users of public transport is to purchase a travelcard with longer validity; however, since they are also the most expensive in absolute terms, low-income earners may be dissuaded from purchasing monthly travelcards and instead rely on more expensive weekly travelcards or single tickets, or refrain from travelling all together (Jones and Lucas 2012). One explanation for such behaviour is an actual or perceived liquidity constraint that prevents the individual from purchasing the (ultimately) less costly travelcard.

In addition to qualitative studies (Preston and Rajé 2007; Isaksson 2010; Lucas 2011; Blumenberg and Weinstein Agrawal 2014), there is some quantitative evidence to support the existence of a liquidity constraint among less wealthy individuals when buying public transport travelcards. Graham and Mulley (2012) used survey data to study the local effects of a pricing reform in Sydney and showed that the upfront cost of a pre-paid travelcard appear to dissuade low-income and price-sensitive travellers from purchasing travel in this manner, despite the discount it entails relative to pay-as-you-go tickets. Hickey et al. (2010) studied ticket sales at New York subway stations and found that the proportion of weekly

\footnotetext{
1 The effect described by Mohring (1972) by which incumbent passengers benefit from new passengers as the operator increases supply (frequency) to meet the increased demand.
} 
travelcards registered at subway stations located in low-income neighbourhoods was higher than in more affluent neighbourhoods, in which monthly travelcards were more common. In a more recent study, Verbich and El-Geneidy (2017) expanded on Hickey et al. (2010) and used neighbourhood data from Montréal to examine how ticket sales in low-income areas differ from those in high-income areas. They found that more monthly travelcards were sold in more affluent neighbourhoods and that more weekly travelcards were sold in less affluent neighbourhoods. They also found that three or more consecutive weekly travelcards were more likely to be purchased in low-income neighbourhoods, even though a monthly travelcard cost roughly the same as three weekly travelcards.

The phenomenon described by Jones and Lucas (2012) is therefore highly relevant to policy and research; however, previous studies of the effect of liquidity constraints on ticket purchasing behaviour are either qualitative, based on surveys with limited samples or on local data. This limits the ability to make generalisations and to determine whether income is the deciding factor in low-income earners choosing to buy more expensive tickets. In this study, we use a large individual dataset from the Swedish National Travel Survey investigate how income relates to travelcard possession and whether low-income earners purchase more expensive public transport tickets. By using individual data, we avoid problems with spurious correlation that could be an issue with some of the methods used in previous studies. The large dataset allows us to isolate the effect of income and gain a greater understanding of this phenomenon and show that low income earners indeed purchase more expensive tickets.

We recognise that public transport fares as well as subsidies have other distribution effects (e.g. Borck and Wrede 2005) as well as effects on travel behaviour. One such effect is the more extreme case of the issue at hand whereby some individuals due to what they perceive as high costs for using public transport refrain from travelling altogether. While this might be a very significant effect, especially in the context of transport related social exclusion, it is beyond the scope of this paper. A similar issue, forced car ownership, is explored by for example Currie and Sendbergs (2007) and Curl et al. (2018). Forced car ownership implies that individuals in various ways, for example by high public transport fares or poor supply, are forced to own and drive a car, which in most cases entail a higher financial cost than public transport. The other side of the coin is where those with lower incomes cannot afford to buy a car which in turn limits their employment opportunities, causing further financial stress (Gautier and Zenou 2010). However, these issues are also beyond the scope of this paper. Instead we focus on ticket choices among very frequent public transport users.

The paper is structured as follows: in section "Liquidity constraints" we introduce the concept of liquidity constraints and provide a model for our scenario; in section "Public transport in Sweden" we give a brief overview of public transport organisation and use in Sweden; in section "Data and method" we present the data used and the method employed; in section "Do the poor pay more?", the results are presented; in section "Discussion", we discuss the results and in section "Conclusions" we offer some concluding remarks. 


\section{Liquidity constraints}

\section{Basic theory}

One factor that may cause individuals to buy more expensive tickets is liquidity constraints. This concept has been used to explain food consumption (Zeldes 1989), savings (Deaton 1991), consumption using credit cards (Gross and Souleles 2002) and firm investment behaviour (Audretsch and Elston 2002).

Economic consumption theory typically assumes that individuals make financial decisions that maximise utility. This generally implies that if an individual can make an investment that saves them money, he or she will make that investment; however, if an individual does not have sufficient funds at the time, they may borrow against future income in order to invest (Friedman 1957). This rests on the assumption that the individual can borrow without transaction costs, which is not true in the real world (Pissarides 1978). Since the individual cannot always borrow to smooth income over the lifecycle, they will not always be able to afford the investment. Hence, the individual will be faced with liquidity constraints that leave them unable to make the best financial decisions. Without the funds to make optimal financial decisions, they will have less funds in the next period, potentially reinforcing the liquidity constraint.

\section{The case of ticket prices}

Perhaps the best-known model for determining ticket choice in public transport was that developed by Carbajo (1988). The model assumes that the consumer will predict their travel consumption with and without a travelcard over the period for which the ticket choice is made. The consumer will then compare the utility and the cost of travel with and without a travelcard and choose the alternative that provides him/her with the highest utility. This model has been applied by for example Jara-Diaz et al. (2016) to identify and assess the consequences of optimal fares in Santiago, Chile.

The model assumes that an individual can afford any kind of ticket and can maximise utility. While this might be true for a large part of the population-at least in wealthier parts of the world-both qualitative studies (e.g. Preston and Rajé 2007; Isaksson 2010; Lucas 2011; Blumenberg and Weinstein Agrawal 2014) and quantitative studies (e.g. on Hickey et al. 2010; Verbich and El-Geneidy 2017) suggest that low-income groups could face liquidity constraints. These constraints cause them to either refrain from travelling altogether or purchase more expensive pay-as-you-go or pre-paid single-trip tickets.

We described this in a model with two time periods, $t=\{1,2\}$. Let $Y, r, n_{t}$, and $p_{s}$ and $p_{c}$ denote the income (or the budget allocated to transport), the interest rate, the number of trips per period, and the price of a single trip $(s)$ or travelcard $(c)$. Transport costs consist either of the number of trips times the price of single tickets or the price of a travelcard that grants unlimited access to transport in both periods. The liquidity-constrained individual is assumed to prefer to allocate his/her budget evenly over the two time periods (i.e. $Y_{t}=Y / 2$ ); reason could be so that he/she is able to cover unexpected expenditures. Furthermore, we assume that the total budget is at least as large as the cost of travel, that the card is less expensive than buying single tickets and that the price of the card is higher than the subperiod budget; i.e., 


$$
Y \geq\left(n_{1}+n_{2}\right) p_{s}>p_{c}>\frac{Y}{2}
$$

Individuals are assumed to gain utility from consumption. We define residual consumption, $C_{i}, i=\{s, c\}$, as the consumption after travel costs have been covered. Equations (2) and (3) show the residual consumption for the liquidity constrained individual $\left(\mathrm{C}_{\mathrm{s}}\right)$ and a non-liquidity-constrained individual $\left(\mathrm{C}_{\mathrm{c}}\right)$ (individuals are assumed identical in all other regards),

$$
\begin{gathered}
C_{s}=\frac{Y}{2}-n_{1} p_{s}+\frac{\frac{Y}{2}-n_{2} p_{s}}{1+r} \\
C_{c}=Y_{1}-p_{c}+\frac{Y-Y_{1}}{1+r}
\end{gathered}
$$

For simplicity, assume that $Y_{1}=p_{c}$, i.e. the non-liquidity-constrained individual's budget for the first period equals the cost of the card, and that $n_{1}=n_{2}=n / 2$, i.e. the number of trips are identical between the periods, then we can show that

$$
C_{s}=\frac{Y}{2}-\frac{n}{2} p_{s}+\frac{\frac{Y}{2}-\frac{n}{2} p_{s}}{1+r}<Y_{1}-p_{c}+\frac{Y-p_{c}}{1+r}=C_{c}
$$

that is,

$$
C_{c}>C_{s} \Leftrightarrow 2\left[\frac{Y-p_{c}}{Y-n p_{s}}-1\right]>r
$$

So, when the inequality holds, the residual consumption is less for the liquidity-constrained individual. If we assume that utility is increasing in $\mathrm{C}$, the liquidity-constrained individual is therefore left with a lower overall utility than the non-liquidity-constrained individual. This inequality will hold unless the individual discount rate is high. In this paper we examine the purchase of monthly travelcards; for example, if we assume that $\mathrm{p}_{\mathrm{c}}=0.05 \cdot \mathrm{Y}$ and $\mathrm{p}_{\mathrm{s}}=0.07 \cdot \mathrm{Y}$, then the inequality holds for $\mathrm{r}_{\text {monthly }}<4.3 \%$. Hence, unless the individual has a very high utility discount rate, he/she is better off buying the monthly travelcard. There is empirical evidence that suggest that those with lower incomes have higher discount rates (e.g. Harrison et al. 2002), however, it is difficult to determine if these differences stem from differences in preferences or is a result of liquidity constraints.

\section{Public transport in Sweden}

\section{Organisation and fares}

Public transport in Sweden is organised into 21 regional public transport authorities (PTAs). The PTAs are generally politically governed at the regional level; however, the municipalities have large influence over supply. In northern Sweden the municipal supply is typically organised separately from the regional supply. The main task of the PTAs is to tender busses and regional trains (one PTA operate its own busses) within the region. Since 2012 the PTAs are also allowed to tender or operate interregional traffic. There are four major interregional train systems: Norrtåg which operate in northern Sweden, Tåg i 
Bergslagen which operate in central Sweden, Mälab which operate in the densely populated Mälardalen region (Stockholm is located in the Mälardalen region) and Öresundståg which operate in southern Sweden. The Stockholm PTA also responsible for operating the Stockholm metro and a few PTAs operate tram lines.

The fares differ a lot between PTAs, both in terms of zone structure, price and the discounts offered. Most PTAs have a zone-based fare structure with lower prices within zones and higher prices between zones. The exceptions from this are the Stockholm PTA that have a single zone and some of the PTAs in northern Sweden which have distance-based fares outside the cities. All PTAs offer single tickets as well as monthly cards which allow the travellers to travel as much as they like within the zones for which the cards are eligible. In some cases, there are also a small additional time cost associated with purchasing a single ticket. ${ }^{2}$

All but one (Norrbotten) PTA offer some form of discount on monthly travelcards for students while all offer student discounts on single tickets. Of the PTAs, 13 out of 21 offers discounted monthly travelcards for the elderly $(65+)$, although only seven offer reduced price single tickets for the same group. All PTAs offering reduced price single tickets also offer a reduced-price monthly card for elderly. Some PTAs also offer discounts for people of certain welfare statuses, i.e. if you are unable to work because of an illness or disability or if you have a serious handicap which involves significant expenses, in these cases these individuals are offered the same discounts as seniors. ${ }^{3}$ A summary of the most important discounts is presented in Table 1 .

\section{Public transport and income}

The main data source of this study is the Swedish National Travel Survey collected by Statistics Sweden (SCB) on behalf of the government agency Transport Analysis between 2011 and 2016. From the survey it is possible to discern several differences, not only in how public transport patronage varies by income but also geographically. Public transport patronage is widespread among those with very low and low incomes; however, there are geographical differences apparent when comparing Figs. 1 and 2. In Sweden's three metropolitan regions, public transport use is widespread even among more affluent individuals; a pattern that is even more distinct In Stockholm. It is those living in the metropolitan regions, and especially Stockholm, who make up the group of high-income earners who also travel by public transport five to seven days per week. In the rest of the country, public transport use is more common among those with very low income (annual income below SEK 100,000) relative to those with higher incomes. Outside the three metropolitan regions, it appears as if those that can afford to travel by other means to a larger extent choose to do so.

We can also observe how much different households on average spend on public transport using the Swedish household expenditure survey (HUT) (SCB 2017a). The most recent results are from 2006 to 2009 due to low response rates in later surveys. Regardless

\footnotetext{
${ }^{2}$ For the purposes of this paper we treat this additional time cost as negligible and focus on the monetary costs associated with ticket purchases.

3 This "welfare group" constitutes about 4 per cent of the population. About half of these are individuals who retired earlier due to an illness. These people receive their pension through the social insurance system until they turn 65, however, as senior discounts are based on age this group receives their discount based on their welfare status.
} 
Table 1 Discounts

\begin{tabular}{llllll} 
Monthly card & & & Single ticket & \\
\cline { 1 - 3 } Youth/student & Senior & $\begin{array}{l}\text { Welfare } \\
\text { statuses }\end{array}$ & Youth/student & Senior \\
\hline
\end{tabular}

\begin{tabular}{|c|c|c|c|c|c|}
\hline Blekinge & Yes & Yes & & Yes & Yes \\
\hline Dalarna & Yes & Yes & & Yes & No \\
\hline Gotland & Yes & Yes & & Yes & Yes \\
\hline Gävleborg & Yes & Yes & Yes & Yes & No \\
\hline Halland & Yes & No & & Yes & No \\
\hline Jämtland & Yes & Yes & Yes & Yes & No \\
\hline Jönköping & Yes & Yes & & Yes & $\mathrm{No}^{\mathrm{J}}$ \\
\hline Kalmar & Yes & Yes & Yes & Yes & No \\
\hline Kronoberg & Yes & No & & Yes & No \\
\hline Norrbotten & No & No & & Yes & Yes \\
\hline Skåne & Yes & No & & Yes & No \\
\hline Stockholm & Yes & Yes & & Yes & Yes \\
\hline Södermanlands & Yes & No & & Yes & No \\
\hline Uppsala & Yes & Yes & Yes & Yes & No \\
\hline Värmland & Yes & $\mathrm{No}^{\mathrm{T}}$ & Yes & Yes & No \\
\hline Västerbotten & Yes & Yes & & Yes & Yes \\
\hline Västernorrland & Yes & Yes & & Yes & Yes \\
\hline Västmanland & Yes & $\mathrm{Yes}^{\mathrm{V}}$ & & Yes & $\mathrm{Yes}^{\mathrm{V}}$ \\
\hline Västra Götaland & Yes & Yes & Yes & Yes & No \\
\hline Örebro & Yes & No & & Yes & No \\
\hline Östergötland & Yes & Yes & & Yes & Yes \\
\hline
\end{tabular}

${ }^{\mathrm{W}_{T}}$ The regions that specifically report that they offer discounts for some welfare statuses

${ }^{\mathrm{T}}$ Not in general, but there are discounts for some cards

${ }^{\mathrm{V}}$ Only in the major city, which make up 57 per cent of the population

${ }^{\mathrm{J}}$ Not in general but in some municipalities

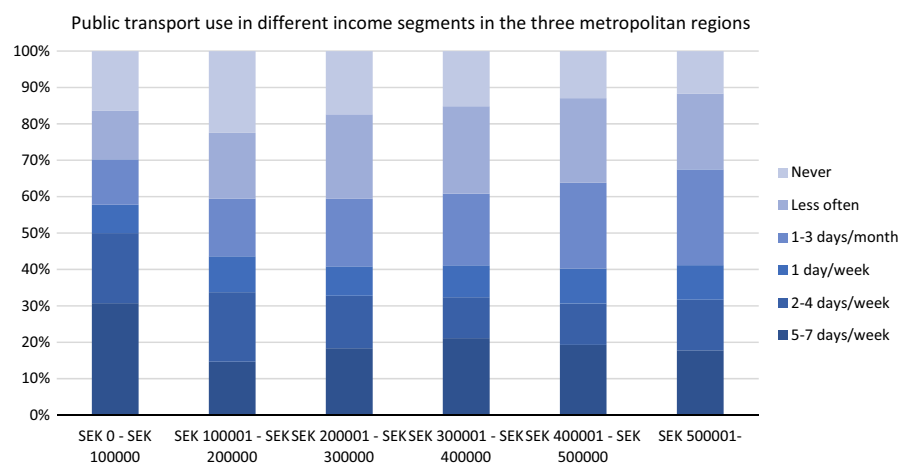

Fig. 1 Response to "How often do you typically use public transport?" in the three metropolitan regions. Only respondents 19 years old and above who stated income. EUR $1 \approx$ SEK 10 


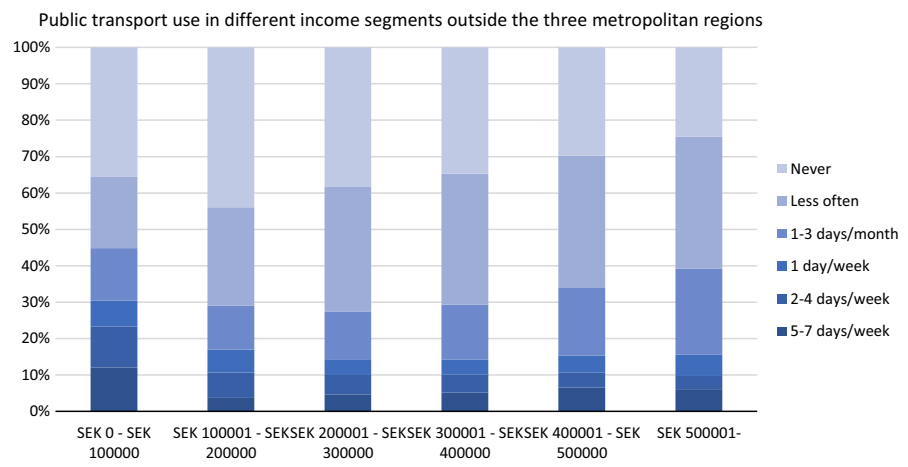

Fig. 2 Response to "How often do you typically use public transport?" outside the three metropolitan regions. Only respondents 19 years old and above who stated income. EUR $1 \approx$ SEK 10

of this, the survey shows a distinctive pattern in public transport expenses. Public transport's (including transport services, i.e. taxis) share of disposable income per income decile is presented in Table 2.

The percentage of income spent on public transport ranges from about 3 per cent for the first decile down to about 1 per cent for the eighth decile. The total share of disposable income spent on transport (public transport, car, etc.) has an opposite shape to that of the share spent on public transport ranging from nine percent (the first decile) to 18 percent (the eight decile). This could suggest that low income individuals not only use public transport more, they also spend a larger share of their income on public transport.

\section{Data and method}

\section{Subsample: very frequent travellers}

The analysis utilises individual data from the Swedish National Travel Survey. The survey contained a travel diary for a selected day (All 365 days of a year are represented in the sample, with sampled individuals being randomly assigned to specific days). Participants also responded to questions about access to a car, internet, travelcards, as well as other background information, e.g. income. In total, 48,629 individuals living in Sweden participated in the survey.

To investigate whether low-income frequent travellers also buy more expensive tickets, we studied the individuals who in the Swedish National Travel Survey stated that they typically use public transport between five to seven days a week. Since we did not have complete information regarding the fare structure of each PTA for each year of the survey, we have based our analysis on the least expensive ticket for these very frequent travellers being a monthly travelcard or a travelcard with an even longer period of validity. ${ }^{4}$ To validate this, we collected prices for single tickets and monthly travelcards for a number of

\footnotetext{
4 There could of course be cases where some people travel to some zones some days and other zones other days which would cause them to refrain from purchasing a monthly travelcard. This issue will be dealt with in a sensitivity analysis presented in Sect. Discussion.
} 


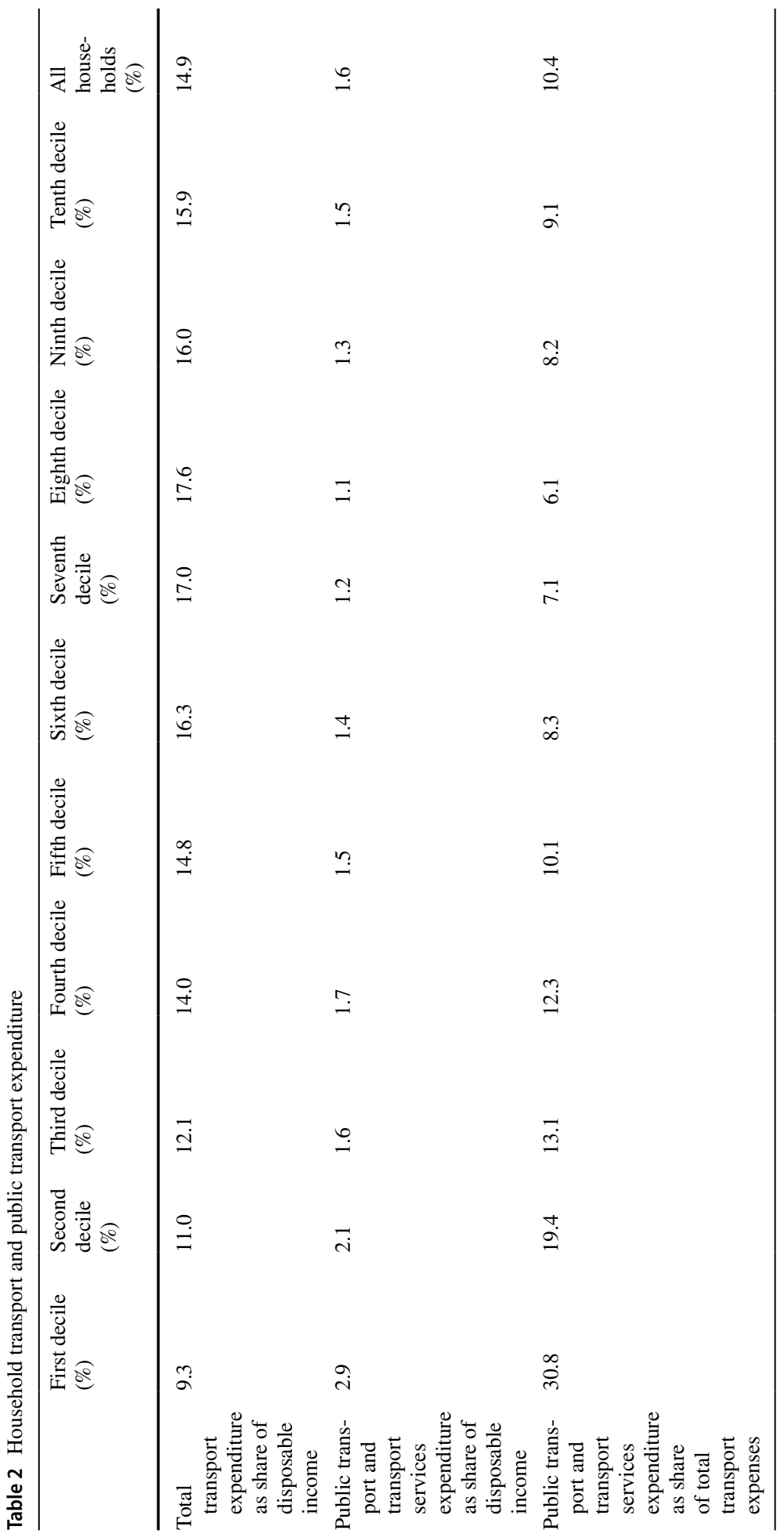




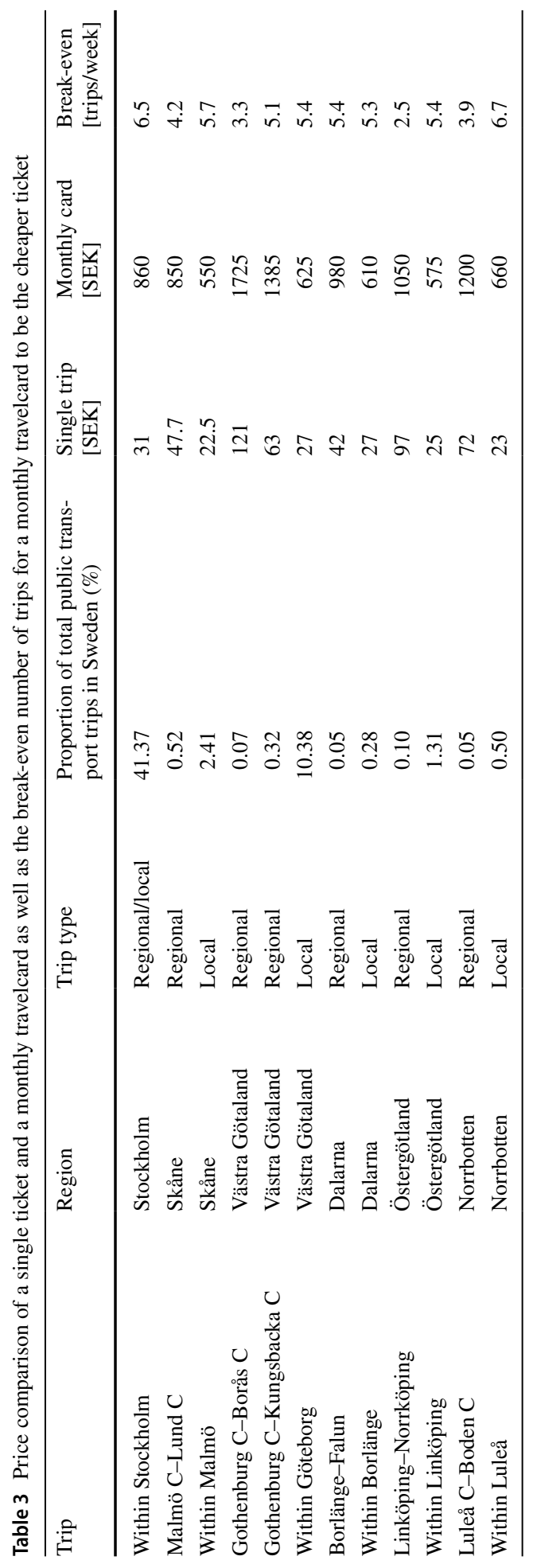




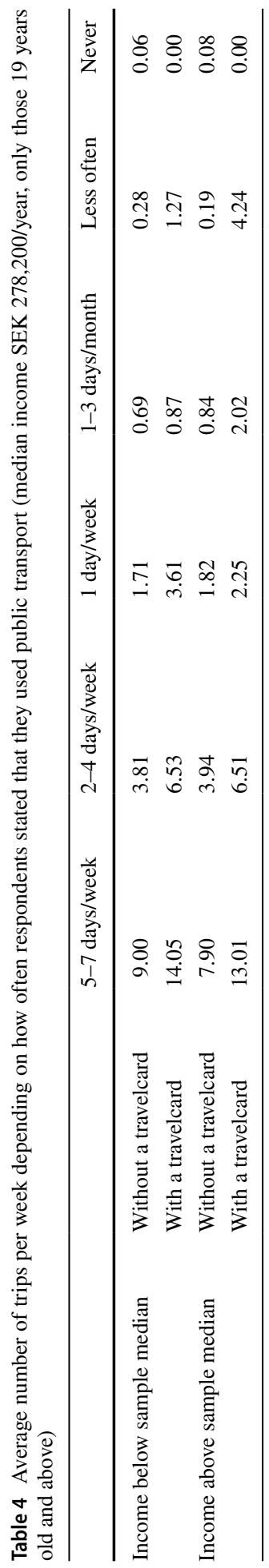


significant public transport journeys in Sweden. These are presented in Table 3. For most journeys, the break-even is below six trips per week and below seven for all journeys. The discounts presented in section "Public transport and income" should not shift or lower the number of trips required for a travelcard to be the least expensive option given that the users travel on public transport between five to seven days a week.

It is reasonable to assume that individuals who state that they use public transport between five to seven days a week are likely to make more than seven trips per week. The average number of trips made on the day of the survey is 1.7 which corresponds to 12 trips per week. In Table 4, the average number of trips for all available responses to the question "How often do you typically travel by public transport?" are presented. From the table, it is possible to further validate our assumption that those travelling between five to seven days per week undertake enough journeys to benefit from a monthly travelcard as well as to see that this holds both for those below sample median income and for those without a monthly travelcard. Thus, it is also reasonable to assume that, for those travelling on five to seven days per week, the monthly travelcards is the least expensive ticket. The reason for not using the number of trips on the survey day as our sole identification variable is because it only represents the respondents travel behaviour on the day of the survey.

In total, 8292 respondents stated that they use public transport between five to seven days a week. ${ }^{5}$ The high number of frequent public transport users (17 per cent of the gross sample) is a consequence of oversampling from Västra Götaland region, where public transport patronage is relatively high. Of the 8292 respondents, 6097 agreed to state their income, of whom 5302 were 19 years of age or over. ${ }^{6}$ These individuals make up our sample. ${ }^{7}$ The geographical distribution of the respondents in the samples is presented in Table 5.

As a consequence of our method, we do not have a representative sample of the Swedish population as a whole but rather a sample of the Swedish population that use public transport between five to seven days a week. Apart from the oversampling from Västra Götaland region (which will be dealt with later in a sensitivity analysis) this can be expected to be a representative sample of the inhabitants of Sweden that use public transport between five to seven days per week. Since we are interested in a phenomenon that we assume can only arise in this group, we are only concerned with how representative our sample is of this group. Although there may also be cases of people travelling on two to four days a week buying unnecessarily expensive tickets, we have chosen not to include those since we cannot credibly identify those that travel sufficiently to benefit from a travelcard. Apart from Stockholm, which is much more densely urbanised and has a much higher percentage of the population living in the City of Stockholm, all Swedish regions conform to a similar pattern with one or a few urban centres and surrounding rural regions.

\footnotetext{
5 We assume that there is no systematic bias in how individuals may have over- or understated how often they use public transport. Thus, from this point on we assume that the respondents accurately stated how often they use public transport.

6 We choose 19 years as this is the age that most Swedes graduate from upper secondary school and either enter employment or higher education and typically become financially independent of their parents. Many young people in upper secondary school or below (dependent on the distance between their home and school) also receive free travel passes to travel to school which could disturb the analysis.

7 Two outliers with an individual income of above SEK 2,000,000 per year were subsequently removed. This did not impact the results of the analysis.
} 


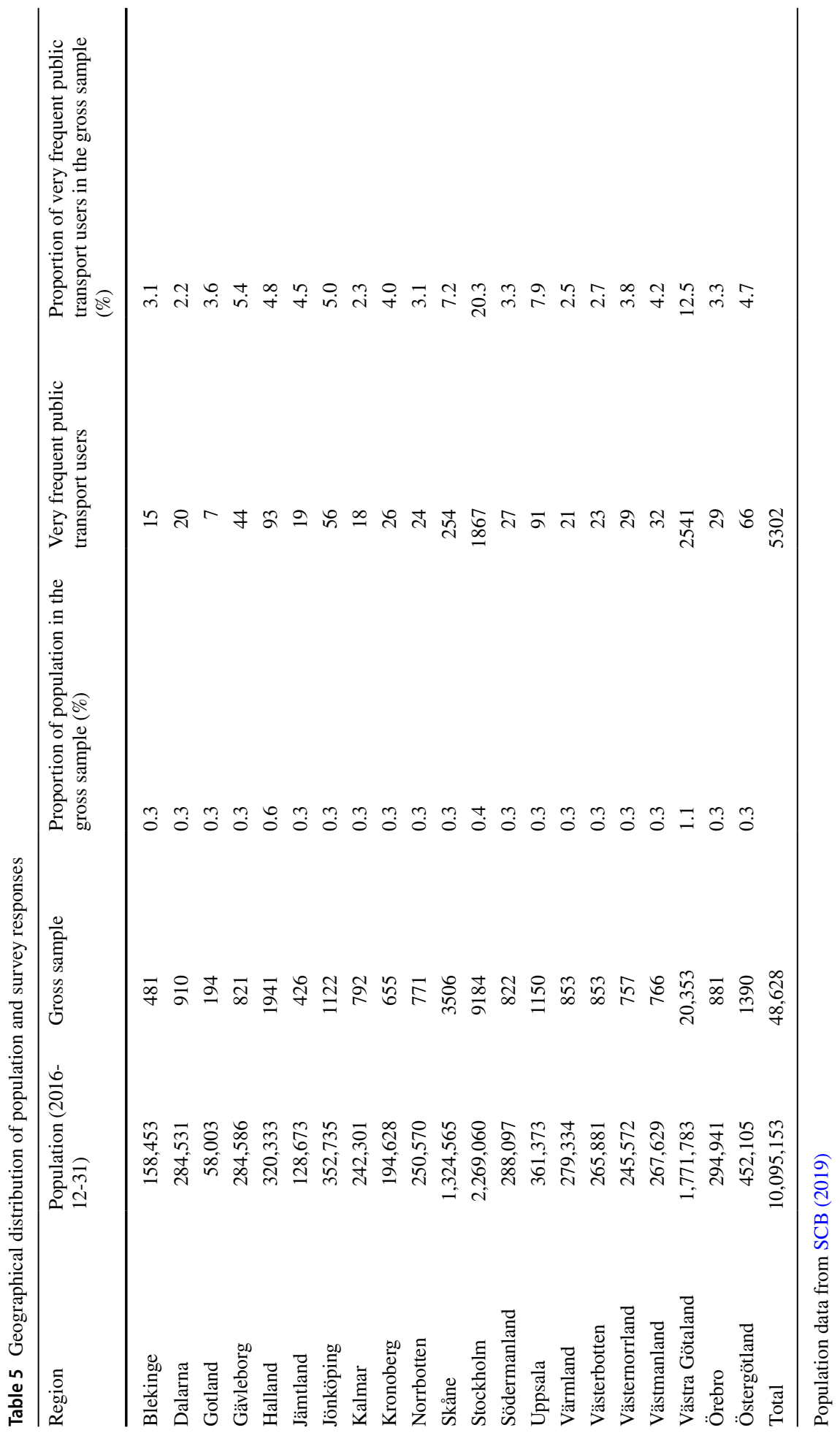




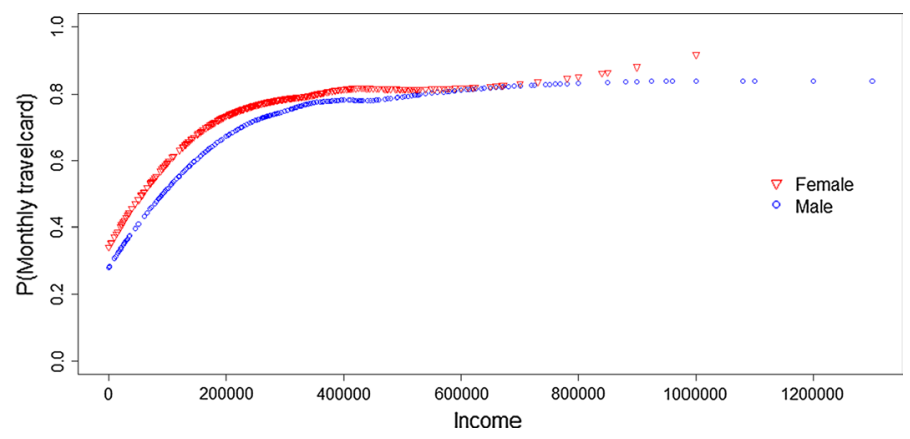

Fig. 3 Loess regression of monthly travelcard possession as a function of income. excluding retirees and students

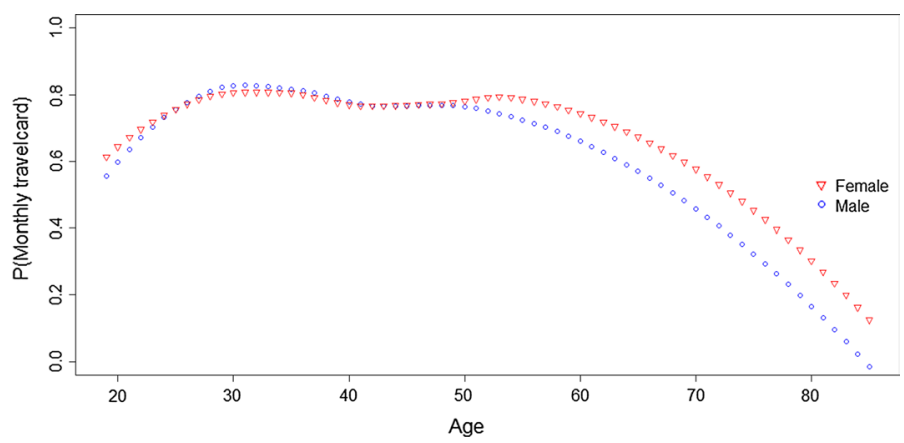

Fig. 4 Loess regression of monthly travelcard possession as a function of age. Including retirees and students

A non-parametric analysis (LOESS regression ${ }^{8}$ ) of the relationship between travelcard possession and income in our sub-sample of very frequent public transport users, presented in Fig. 3, revealed the initial positive relationship between income and monthly travelcard possession. Above a threshold annual income of approximately SEK 230,000, ${ }^{9}$ the relationship is less prominent.

A corresponding analysis of the relationship between travelcard possession and age was also conducted and is presented in Fig. 4. The figure reveals that travelcard possession increases up until the age of 30 years, after which time it is roughly constant until the age of around 50 years, at which point the likelihood of possession begins to decline. In neither of the two figures is travelcard possession 100 per cent. There are several possible explanations for this, perhaps the most plausible being that during holiday months such as July and August it is financially sound to refrain from purchasing a travelcard.

\footnotetext{
${ }^{8}$ The LOESS regression is a non-parametric regression that can be interpreted as a moving average. For a more in-depth explanation of the LOESS-regression see, e.g., Fox and Weisberg (2018).

${ }^{9}$ The average rate of exchange for one Euro during the last year of the survey (2016) was SEK 9.47 (Sveriges Riksbank 2019).
} 


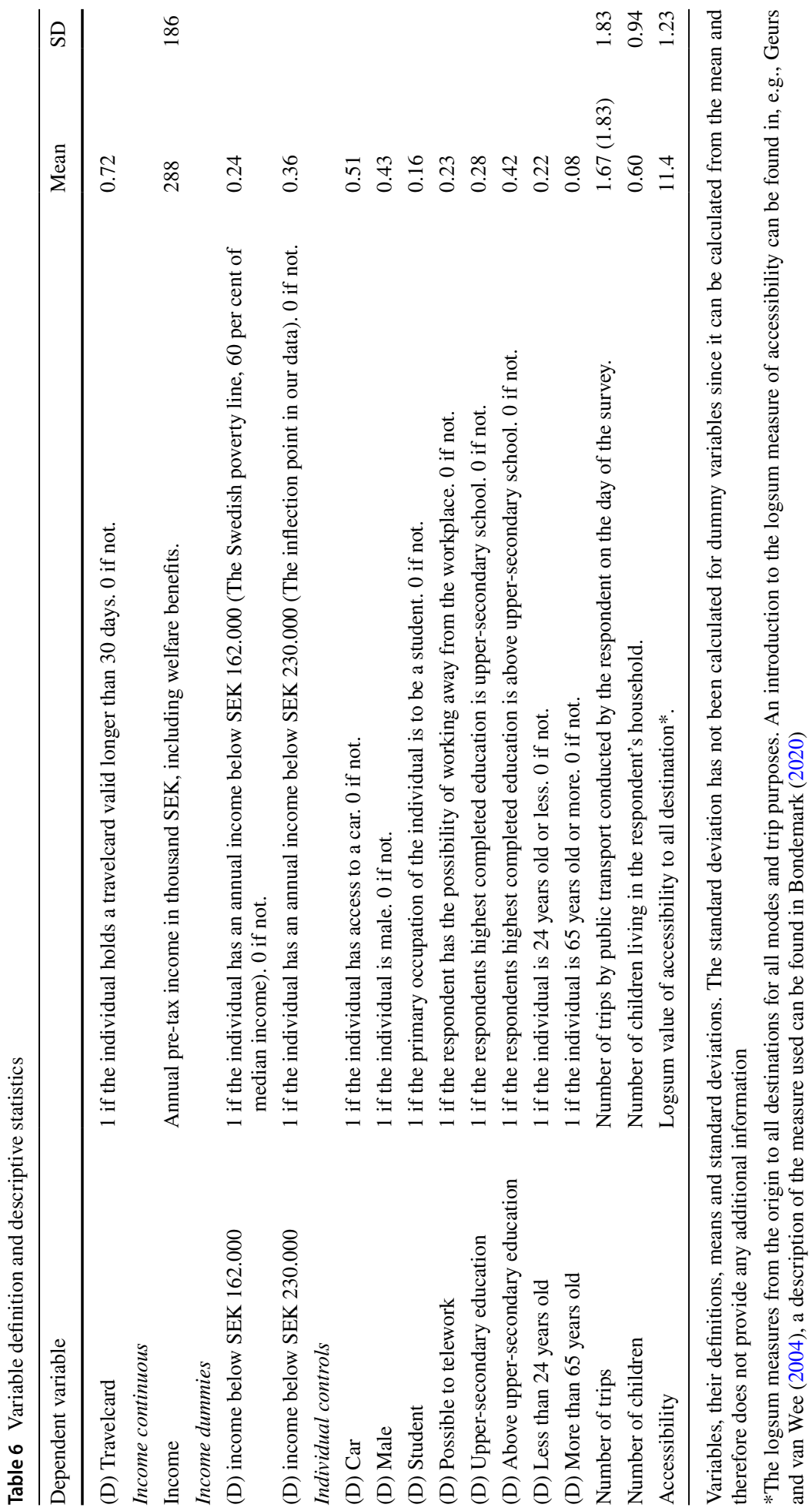




\section{Models used}

To study the effect of income on travelcard possession, we employed a binary logit model:

$$
P_{T P}=\Lambda\left(\alpha_{1}+I_{c} \beta_{1}+X^{\prime} \gamma_{1}+\varepsilon\right)
$$

where $P_{T P}$ is the probability of an individual possessing a monthly travelcard, $I_{c}$ is income (also run as dummies for low-income $I_{\text {low }}$ ), $\beta_{1}$ the parameter for income, $X^{\prime}$ is a vector of variables controlling for other factors expected to influence travelcard possession presented in Table $6, \gamma$ are the corresponding parameters. To better model the inflection point in the curve visible in Fig. 3, we interacted $I_{\text {low }}$ with $I_{c}$.

$$
P_{T P}=\Lambda\left(\alpha_{2}+I_{c} \beta_{2}+I_{c} I_{l o w} \beta_{3}+I_{l o w} \beta_{4}+X^{\prime} \gamma_{2}+\varepsilon\right)
$$

where $\beta_{2}, \beta_{3}$, and $\beta_{4}$ are the corresponding parameters. The variables we used are based on variables from the National Travel Survey. ${ }^{10}$ Some variables, for example, the dummies for low income, have been constructed from the income variable. The definition of low income used in (D) Income below SEK 162,000, is the definition used by Statistics Sweden (SCB $2017 \mathrm{~b}$ ) and applies to some 1,400,000 Swedes (14 per cent of the population).

The mean income in the sample is slightly lower than the average income in Sweden. ${ }^{11}$ When removing students, the proportion of low-income earners drops from 24 to 13 per cent.

\section{Do the poor pay more?}

In Table 7, three models are presented: Model A, containing income only, shows the positive effect of income on the probability of possessing a travelcard. In Model B we added other controls such as car access, gender, age, education and number of journeys taken on the day of the survey. ${ }^{12}$ The income parameter remained significant. The positive impact of the ability to telework could be perceived as unintuitive; however, further analysis indicate that it partly picks up the effect of employment and therefore income, you cannot telework if you are unemployed. Also, the possibility to telework does not necessarily equates using such a possibility, furthermore it could be the case that these individuals have occupations that require them to spend time with customers etc., thereby increasing their travel demand. The positive sign on the parameter for number of trips on the survey day shows that, within the frequent traveller group, those individuals who travel more are also more likely to possess a travelcard. Being a student also has a significant positive impact on travelcard possession. This is likely an effect of the significant discount that students enjoy, combined with a high travel demand resulting from an active social life and the large amounts of spare time characteristic of higher education. The negative effect of being a man on travelcard possession could in part, at least in metropolitan areas where public transport patronage is high, be the result

\footnotetext{
${ }^{10}$ Except for accessibility which we obtained from the Swedish Transport Administration's national transport model SAMPERS. For a brief introduction to SAMPERS see Beser and Algers (2002).

11 SEK 295,462/year excluding welfare benefits, in 2016 (SCB 2017c).

12 Other variables, primarily those related to employment status, were tested but were found to be highly correlated with income. We therefore excluded them from the main analysis.
} 
Table 7 Determinants of monthly travelcard possession

\begin{tabular}{|c|c|c|c|}
\hline & \multicolumn{3}{|c|}{ Dependent variable: } \\
\hline & \multicolumn{3}{|c|}{ Travelcard $=1$} \\
\hline & (A) & (B) & (C) \\
\hline Income & $\begin{array}{l}0.001 \text { *** } \\
(0.0002)\end{array}$ & $\begin{array}{l}0.001 * * * \\
(0.0003)\end{array}$ & \\
\hline (D) income below SEK 162.000 & & & $\begin{array}{l}-0.559^{* * * *} \\
(0.108)\end{array}$ \\
\hline (D) $\mathrm{Car}$ & & $\begin{array}{l}-0.202^{* *} \\
(0.073)\end{array}$ & $\begin{array}{l}-0.187^{* *} \\
(0.072)\end{array}$ \\
\hline (D) Male & & $\begin{array}{l}-0.173 * \\
(0.070)\end{array}$ & $\begin{array}{l}-0.134^{\prime} \\
(0.069)\end{array}$ \\
\hline (D) Student & & $\begin{array}{l}0.875^{* * *} \\
(0.117)\end{array}$ & $\begin{array}{l}1.027 * * * \\
(0.126)\end{array}$ \\
\hline Number of trips & & $\begin{array}{l}0.250^{* * * *} \\
(0.022)\end{array}$ & $\begin{array}{l}0.250^{* * * *} \\
(0.022)\end{array}$ \\
\hline Number of children & & $\begin{array}{l}-0.034 \\
(0.042)\end{array}$ & $\begin{array}{l}-0.022 \\
(0.042)\end{array}$ \\
\hline (D) Possible to telework & & $\begin{array}{l}0.241^{*} \\
(0.100)\end{array}$ & $\begin{array}{l}0.310^{* *} \\
(0.096)\end{array}$ \\
\hline (D) Upper-secondary education & & $\begin{array}{l}0.662 * * * \\
(0.090)\end{array}$ & $\begin{array}{l}0.621^{* * * *} \\
(0.089)\end{array}$ \\
\hline (D) Above upper-secondary education & & $\begin{array}{l}0.633 * * * \\
(0.092)\end{array}$ & $\begin{array}{l}0.637 \text { *** } \\
(0.091)\end{array}$ \\
\hline (D) Less than 24 years old & & $\begin{array}{l}-0.334 * * \\
(0.107)\end{array}$ & $\begin{array}{l}-0.292^{* *} \\
(0.108)\end{array}$ \\
\hline (D) More than 65 years old & & $\begin{array}{l}-1.637 * * * \\
(0.122)\end{array}$ & $\begin{array}{l}-1.588^{* * * *} \\
(0.122)\end{array}$ \\
\hline Regional controls & Yes & Yes & Yes \\
\hline Constant & $\begin{array}{l}1.299^{* * * *} \\
(0.092)\end{array}$ & $\begin{array}{l}0.761 * * * \\
(0.139)\end{array}$ & $\begin{array}{l}1.168^{* * * *} \\
(0.118)\end{array}$ \\
\hline Observations & 5.300 & 5.300 & 5.300 \\
\hline Log Likelihood & -2.946 & -2.656 & -2.650 \\
\hline McFadden $\mathrm{R}^{2}$ & 0.057 & 0.150 & 0.152 \\
\hline Akaike Inf. Crit. & 5.937 & 5.376 & 5.364 \\
\hline
\end{tabular}

Parameters with robust SE in parenthesis. Significance codes: $0<* * *<0.001<* *<0.01<*<0.05<'<0.1$

of higher bicycle use among Swedish males compared to Swedish females (Transport Analysis 2015). Since bicycles are, in many cases, a substitute to public transport, this might slightly reduce the gain from travelcard possession among males. With regards to car ownership both Simma and Axhausen (2001) and Scott and Axhausen (2006) show that there is a trade-off between car ownership and season tickets. While the correlation between monthly travelcards and car access is very low in our dataset there is a negative correlation between car access and number of public transport trips. It might therefore 
Table 8 Determinants of monthly travelcard possession

\begin{tabular}{|c|c|c|c|}
\hline & \multicolumn{3}{|c|}{ Dependent variable: } \\
\hline & \multicolumn{3}{|c|}{ Travelcard $=1$} \\
\hline & (I) & (II) & (III) \\
\hline Income & $\begin{array}{l}0.0004 \\
(0.0003)\end{array}$ & $\begin{array}{l}0.0003 \\
(0.0004)\end{array}$ & $\begin{array}{l}0.0003 \\
(0.0004)\end{array}$ \\
\hline Income * (D) income below SEK 162.000 & $\begin{array}{l}0.003 * \\
(0.001)\end{array}$ & & \\
\hline (D) income below SEK 162.000 & $\begin{array}{l}-0.776^{* * *} \\
(0.195)\end{array}$ & & \\
\hline Income * (D) income below SEK 230.000 & & $\begin{array}{l}0.004 * * * \\
(0.001)\end{array}$ & $\begin{array}{l}0.005 * * * \\
(0.001)\end{array}$ \\
\hline (D) income below SEK 230.000 & & $\begin{array}{l}-0.918 * * * \\
(0.203)\end{array}$ & $\begin{array}{l}-0.988^{* * * *} \\
(0.222)\end{array}$ \\
\hline Accessibility & & & $\begin{array}{l}-0.105^{* *} \\
(0.039)\end{array}$ \\
\hline Controls from Table 4 & Yes & Yes & Yes \\
\hline Regional controls & Yes & Yes & Yes \\
\hline Constant & $\begin{array}{l}1.394 * * * \\
(0.192)\end{array}$ & $\begin{array}{l}1.454 * * * \\
(0.203)\end{array}$ & $\begin{array}{l}2.709 * * * \\
(0.531)\end{array}$ \\
\hline Observations & 5.300 & 5.300 & 4.755 \\
\hline Log Likelihood & -2.637 & -2.637 & -2.302 \\
\hline McFadden $\mathrm{R}^{2}$ & 0.156 & 0.156 & 0.160 \\
\hline Akaike Inf. Crit. & 5.365 & 5.364 & 4.694 \\
\hline
\end{tabular}

Parameters with robust SE in parenthesis. Significance codes: $0<* * *<0.001<* *<0.01<*<0.05<{ }^{\prime}<0.1$ The lower number of observations in model (III) is due to differences in the neighbourhood division used by Statistics Sweden and The Swedish Transport Administration

be the case that car access impacts travelcard possession through the number of public transport trips undertaken.

In Model C, we replaced the continuous income variable with a dummy for those individuals with an annual income below SEK 162,000. The dummy was significant, suggesting that a low income reduces the probability of an individual purchasing a travelcard. All controls retained their parameter values and significance and the explanatory power of the model also rose slightly. In addition, as a sensitivity test, we examined the effect of a "high income dummy", which proved to be statistically insignificant. ${ }^{13}$

The results from Model C predict that a 30-year old working female with no children, no car and an upper-secondary education who makes two public transport trips per day has an 18 per cent higher probability (11 percentage points) of having a travelcard if she does not have an income below the low-income threshold. To better reflect the inflection point

\footnotetext{
13 While Statistics Sweden does not have a definition of "high income", the European Union applies 230 per cent of median income. When we included this in the regression, it turned out to be non-significant and did not affect the other parameters.
} 
Table 9 Sensitivity analysis

\begin{tabular}{llll}
\hline & \multicolumn{2}{l}{ Dependent variable: } \\
\cline { 2 - 4 } & Travelcard $=1$ & \\
\cline { 2 - 4 } & $(\mathrm{R} 1)$ & $(\mathrm{R} 2)$ & $(\mathrm{R} 3)$ \\
& Excluding Stockholm & $\begin{array}{l}\text { Excluding } \\
\text { Västra Göta- } \\
\text { land }\end{array}$ & $\begin{array}{l}\text { Only Stockholm } \\
\text { and Västra Göta- } \\
\text { land }\end{array}$ \\
\hline & & 0.0001 & 0.0004 \\
Income & 0.0003 & $(0.0005)$ & $(0.0004)$ \\
Income $*$ (D) income below SEK 230,000 & $(0.0005)$ & $0.003^{*}$ & $0.004^{* * *}$ \\
& $0.005^{* * *}$ & $(0.001)$ & $(0.001)$ \\
(D) income below SEK 230,000 & $(0.001)$ & $-0.723^{*}$ & $-0.939^{* * *}$ \\
& $-1.018^{* * *}$ & $(0.299)$ & $(0.229)$ \\
Controls from Table 4 & $(0.243)$ & Yes & Yes \\
Regional controls & Yes & Yes & Yes \\
Constant & Yes & $1.193^{* * *}$ & $1.454^{* * *}$ \\
& $0.571^{\prime}$ & $(0.274)$ & $(0.226)$ \\
Observations & $(0.330)$ & 2.759 & 4.406 \\
Log Likelihood & 3.435 & -1.247 & -2.104 \\
McFadden $\mathrm{R}^{2}$ & -1.877 & 0.196 & 0.141 \\
Akaike Inf. Crit. & 0.147 & 2.582 & 4.260 \\
\hline
\end{tabular}

Parameters with robust SE in parenthesis. Significance codes: $0<*^{* *}<0.001<* *<0.01<*<0.05<{ }^{\prime}<0.1$

in the relationship between income and the probability of travelcard possession visible in Fig. 3, we estimated the models in Table 8 .

The models presented in Table 8 all contain the controls used in Models B and C. The controls retained their parameter estimates and significance. In Model I we allow for a piecewise linear function with different slopes above and below the low-income threshold. This model has a slightly better fit than Model $\mathrm{C}$ and the threshold effects are alleviated as the fictitious woman from the previous paragraph is now only 3 per cent $(2.5$ percentage points) more likely to have a travelcard if she is above the low-income threshold when using parameters from Model I. However, as noted in section "Data and method", the inflection point in the data is not at the low-income threshold but at an annual income of approximately SEK 230,000. Therefore, in Model II we estimated a model similar to Model I but with the threshold moved to SEK 230,000, which improved parameter significance. ${ }^{14}$

In the final model, Model III, we added the accessibility of the respondents' place of residence as a variable. This accessibility variable roughly corresponds the extent to which the respondents live in a city (or at least how easy it is to access a city). The parameter could be expected to have a positive sign, given that public transport generally is more competitive in cities, which would also imply that travelcards are more competitive. Yet, it turns out to be negative. While there might be relationship between urbanisation and

\footnotetext{
${ }^{14}$ As many economic decisions are made on a household level, we also tested the effect of household income per consumption unit on travelcard possession. This resulted in large threshold effects around the inflection point similar, but greater, to those in Model C.
} 
public transport competitiveness in most areas of Sweden, this is not necessarily the case in the monocentric regions of Stockholm and Västra Götaland that dominate the sample. In these regions, the highly accessible locations are in core urban areas in which walking, and cycling are very competitive. Other regions, such as the polycentric Skåne region, have the expected pattern of higher travelcard possession in more accessible locations. That said, both travelcard possession and accessibility are higher in Stockholm and Västra Götaland than in the rest of the country and further analysis shows that the negative sign is an effect within Stockholm and Västra Götaland.

In order to check the robustness of the results and to rule out the possibility that a single region drove the results, we performed sensitivity analyses based on Model II in which we excluded regions. These are presented in Table 9. The reason for choosing Model II over Model III as the basis of the sensitivity analyses is that some observations were lost when adding the accessibility variable in Model III. ${ }^{15}$ In all models the relationship between income and travelcard possession remained significant, suggesting that this effect is not exclusive to either Stockholm, Västra Götaland or the rest of the country. The lower significance in Model R2, in which we excluded the Västra Götaland region, is because this region constitutes such a large part of the sample.

To test if the observed ticket choice simply was an effect of uncertainty about which zones the travellers need access to in the coming month, we studied the relationship between income and travelcard possession in a PTA with only one zone. We therefore estimated Model III (detailed figures not presented for the sake of brevity) using data from only Stockholm (the Stockholm PTA consists of one zone only). In this estimation the parameters in the model retained their size ${ }^{16}$; however, they lost most of their statistical significance, which can be explained by the significantly lower number of observations in the Stockholm sample. This result shows that the observed relationship between income and travelcard possession involves more factors than individuals' uncertainty about this aspect of future demand.

\section{Discussion}

In this paper, we have studied how income explains the possession of monthly travelcards among individuals for whom this would have been the least expensive ticket based on their travel behaviour. We find a consistent positive relationship between income and the probability of travelcard possession which appears to confirm the relationship between income and price paid per trip presented by Jones and Lucas (2012), even in an extensive welfare state such as the Swedish one. Whereas previous empirical studies of this phenomenon have used area-level data (Verbich and El-Geneidy 2017) or a small sample from a specific area (Graham and Mulley 2012), we have used a large individual dataset from the whole of Sweden. We have therefore been able to isolate the effect of income on travelcard possession, as well as conclude that this phenomenon is not unique to a specific urban region but appears in at least the two largest urban regions in Sweden.

\footnotetext{
15 This is a result of the slightly different zones used by Statistics Sweden responsible for conducting the Travel Survey and the Swedish Transport Administration whose model is the basis of the accessibility calculations.

16 Income * (D) income below SEK 230,000: 0.0029 (0.0021), (D) income below SEK 230,000: -0.7071 ' (0.4273).
} 
This represents a substantial overpayment (i.e. what frequent travellers pay for their travel, over and above what they would if they had bought a monthly travelcard). In Stockholm, which has a single-zone system, we can calculate a simple estimate of the overpayment. Expanding the figures (adult population of 1,750,000, 20 per cent very frequent travellers, 15 per cent of which does not possess a travelcard, these make on average 1.36 trips per day and pay, on average, SEK 30 per single ticket) yields an overpayment of SEK 250 million per year, an annual average of SEK 100 per resident of Stockholm. While this might not seem like a lot of money, this expense is not evenly distributed across the population. As the main results of this study show, those travelling without a monthly travelcard typically have a lower income than those travelling with one. This is reflected in the share of their income spent over and above the cost of the monthly card, which add up to, on average, 2 per cent of net income. ${ }^{17}$

The decision to buy a more expensive ticket may seem irrational; however, it is not necessarily the case that a liquidity-constrained individual cannot afford a EUR 100 expenditure. It could be that they, quite rationally, instead buy several single tickets and thus pay more for the entire month but get a smoother consumption profile and are able to cover any unexpected expenditure, such as medicine or an emergency repair, for a greater part of the month. This being the case, purchasing several initially less expensive single tickets may make sense, even though they may incur higher costs over the course of the month.

Another explanation, building on Carbajo's (1988) model, could be that when an individual decides whether or not to purchase a travelcard, there is uncertainty in their assessment of future demand. This might cause some individuals to be uncertain as to whether they will receive the most utility from a travelcard or single tickets. While high-income earners might purchase a travelcard as a form of insurance or to avoid the inconvenience of purchasing single tickets, low-income earners might feel that they cannot afford to make the mistake of paying too much and therefore refrain from purchasing a travelcard, choosing instead to rely on single tickets. On a similar note, it could also be that the prospect of losing an expensive travel card dissuade low-income individuals from purchasing a travel card.

A third explanation relates to the relationship between income and employment. Some people may not know where and when they will be working; for example, those in temporary, casual or zero-hours employment (precarious work). In such cases they may choose to rely on single tickets with varying geographical coverage from day to day, instead of purchasing the more expensive travelcard required to access all zones in a PTA. Even if precarious work is relatively uncommon (in 2014, less than 3 per cent of the Swedish workforce (SCB 2015) were employed in what can be described as precarious work), it is more common among low-income earners, something that may bias the estimates. The result from the sensitivity results using only the Stockholm PTA shows that the observed relationship persists in a one-zone fare system. The relationship between income and travelcard possession therefore involves more factors than individuals' uncertainty about workplace location.

In this study, we have assumed that those individuals who do not have a monthly (or longer) travelcard purchase more expensive tickets. There is however a third option-not paying at all. In Stockholm and Gothenburg, there is a network of individuals functioning

\footnotetext{
17 Average pre-tax income for very frequent travellers without travelcards is SEK 23,210 per month. Income tax at SEK 23,210 is 27 per cent. Average monthly overpayment in this group is calculated to SEK 420.
} 
as an insurance scheme, ${ }^{18}$ whereby the monthly fee (about a tenth of the cost of a travelcard) is used to pay the fines of the members caught in ticket inspections. The members of the network also warn each other about the presence of ticket inspectors. While it is feasible that this "payment method" is more common in low-income groups (Delbosc and Currie 2018), it is unlikely that this accounts for the entire effect of income on travelcard possession. Ticket inspectors also state that the most common form of non-payment is people who travel on a discounted travelcard for which they are not eligible. ${ }^{19}$

While we propose that the relationship between income and the average price per trip is a consequence of liquidity constraints, we realise that this is just one possible explanation among many. Another explanation could for example be the cognitive stress hypothesis put forward by Mani et al. (2013), which states that financial stress induces cognitive stress which in turn causes individuals to make poor financial decisions.

\section{Conclusions}

The accessibility and the mobility of low-income groups is an important reason for subsidising travelcards, the findings of this paper have significant policy implications when designing fare systems. It may be tempting to regard expensive single tickets as an incentive for passengers to switch to using a travelcard but, as we have shown, this may simply exacerbate the situation for disadvantaged groups.

What is important to remember before discussing ways to ease the situation for passengers with low income is that the mobility of disadvantaged groups is one of many public transport policy objectives alongside for example reducing emissions and promoting regional growth. Relatively expensive single tickets compared with tickets with longer validity might for example encourage people to commit to public transport instead of car use with a reduction in negative externalities and an increase in positive externalities as an effect. Directing subsidies to tickets with longer validity might also be a way for PTAs to avoid subsidising visitors which do not contribute via tax (at least in systems based on income tax rather than sales tax). Reducing the price of single tickets as a means of lower the cost for low-income users might thus conflict with other policy objectives.

There are several ways in which the liquidity constraints for low income passengers could be loosened. The most radical is perhaps removing fares altogether. Even though the Estonian experience show positive effects for low income individuals (Cats et al. 2016) it comes at a considerable cost, both fiscal and in terms of economic efficiency. As a means of solving this problem it is not particularly accurate as everyone can benefit from the absence of fares.

A more accurate solution could be a system like the one investigated in New Zealand which would entail discounted public transport tickets for people with low incomes (Genter 2019). However, such a system is not without its costs and has previously been rejected by Auckland because of its high costs (New Zealand Herald 2019). While this system is much more accurate than fare-free system it is not completely uncontroversial. In welfare models favouring general social security, such as the Nordic models, targeted benefits on the grounds of income are considered stigmatising.

\footnotetext{
18 https://planka.nu/. Accessed 17 Jan 2020.

19 Personal communication with ticket inspectors, 12.07.2018 and 09.02.2019.
} 
Another piece of the puzzle could be that employers offer travel cards as benefits to low-income employees. However, in many countries this is a benefit for which recipients must pay tax so the actual benefit to the employee is limited. However, there are variation in tax rules for commuter support among countries (Potter et al. 2006). The employers must also have an incentive to provide their lowest paid employees with a travel card and the system hinges on the cooperation of the employers. It would thus probably be difficult to make the system equal and available to everyone eligible.

Perhaps the most feasible solution to the problem is the current trend of systems of which London's Oyster Card is one example. These systems either relies on a daily/ weekly/monthly cap or credit/debit cards which automatically chooses the cheapest ticket based on the number of trips undertaken. These types of systems have been made possible by advances in payment technology and pave the way for more flexible fare systems and easier price differentiation (e.g. cheaper off-peak tickets). Such a system would not only remove the need on behalf of the passengers to estimate their future demand it would also give them the opportunity to travel at times with lower fares. Such a differentiation would not only give those with lower incomes an opportunity to buy less expensive tickets, it would also increase the economic efficiency of the system. There is, however, a risk that low-income earners, due to less flexible working hours would be forced to travel in peak while wealthier individuals, with more flexible working hours, would be the main benefactors of such a price differentiation. While this is a risk with price differentiation it does not affect the conclusions regarding the credit/debit card-based systems and their ability to reduce the uncertainty concerning future demand. While there are many benefits from such systems it is also important to acknowledge that a lot of people are pleased with the predictable costs in the current systems and might therefore shun away from systems based on single tickets.

While there are ways to address the issue described in this paper the findings also have repercussions on the design of public transport systems, especially if policy makers fail to reform fare systems. If the cost of public transport increases faster than patronage, as is the case in Sweden, the PTAs will be forced to increase fares. While this might not be an issue for most travellers it has significant impacts for low income individuals which might then refrain from purchase travelcards. It is therefore important to be aware of the phenomenon described in this paper when striking a balance between developing public transport systems and catering to the needs of the people already using them.

Acknowledgements This paper has benefited from comments and discussions with Maria Börjesson, Karolina Isaksson, Isak Jarlebring Rubensson, Jean Ryan, Jan-Erik Swärdh, Andreas Vigren as well as participants at the ITEA conference in Paris 12th-14th June 2019. We would also like to thank two anonymous reviewers for their valuable input.

Authors' contributions Anders Bondemark: Conceptualization, Methodology, Formal Analysis, Data Curation, Writing-Original Draft, Writing-Review \& Editing, Visualization, Project Administration. Henrik Andersson: Methodology, Formal Analysis, Writing-Original Draft, Writing-Review \& Editing, Supervision. Anders Wretstrand: Writing-Original Draft, Writing-Review \& Editing, Supervision, Funding acquisition. Karin Brundell-Freij: Methodology, Formal Analysis, Writing-Original Draft, WritingReview \& Editing, Supervision.

Funding Open access funding provided by Swedish National Road and Transport Research Institute (VTI). This study was funded by Lund University.

Availability of data and material We are not able to share data under Swedish law.

Code availability Available upon request 


\section{Compliance with ethical standards}

Conflicts of interest No conflicts of interest.

Open Access This article is licensed under a Creative Commons Attribution 4.0 International License, which permits use, sharing, adaptation, distribution and reproduction in any medium or format, as long as you give appropriate credit to the original author(s) and the source, provide a link to the Creative Commons licence, and indicate if changes were made. The images or other third party material in this article are included in the article's Creative Commons licence, unless indicated otherwise in a credit line to the material. If material is not included in the article's Creative Commons licence and your intended use is not permitted by statutory regulation or exceeds the permitted use, you will need to obtain permission directly from the copyright holder. To view a copy of this licence, visit http://creativecommons.org/licenses/by/4.0/.

\section{References}

Audretsch, D., Elston, J.: Does firm size matter? Evidence on the impact of liquidity constraints on firm investment behavior in Germany. Int. J. Ind. Organ. 20(1), 1-17 (2002)

Basso, L., Jara-Diaz, S.: The case for subsidisation of Urban public transport and the mohring effect. J. Transp. Econ. Policy 44(3), 365-372 (2010)

Beser, M., Algers, S.: SAMPERS—The New Swedish National Travel Demand Forecasting Tool. National Transport Models, pp. 101-118 (2002)

Blumenberg, E., Weinstein Agrawal, A.: Getting around when you're just getting by: transportation survival strategies of the poor. J. Poverty 18(4), 355-378 (2014)

Bocarejo S, J.P., Oviedo H, D.R.: Transport accessibility and social inequities: a tool for identification of mobility needs and evaluation of transport investments. J. Trans. Geogr. 24, 142-154 (2012)

Bondemark, A.: The relationship between accessibility and price: the case of Swedish food stores. J. Transp. Geogr. 82, 102615 (2020)

Borck, R., Wrede, M.: Political economy of commuting subsidies. J. Urban Econ. 57(3), 478-499 (2005)

Brown, A.E.: Fair fares? How flat and variable fares affect transit equity in Los Angeles. Case Stud. Transp. Policy 6, 765-773 (2018)

Börjesson, M., Fung, C.M., Proost, S.: Optimal prices and frequencies for buses in Stockholm. Econ. Transp. 9, 20-36 (2017)

Carbajo, J.: The economics of travel passes: non-uniform pricing in transport. J. Transp. Econ. Policy 22(2), 153-173 (1988)

Cats, O., Susilo, Y.O., Reimal, T.: The prospects of fare-free public transport: evidence from Tallinn. Transportation 44, 1083-1104 (2016)

City of Vancouver: Transportation 2040: Moving forward (2012). Available: https://vancouver.ca/files/cov/ transportation-2040-plan.pdf. Accessed 18 Feb 2019

Curl, A., Clark, J., Kearns, A.: Household car adoption and financial distress in deprived urban communities: a case of forced car ownership? Transp. Policy 65, 61-71 (2018)

Currie, G., Sendbergs, Z.: Exploring forced car ownership in metropolitan Melbourne. Australasian Transport Research Forum 2007 (2007)

Deaton, A.: Savings and liquidity constraints. Econometrica 59(5), 1221-1248 (1991)

Delbosc, A., Currie, G.: Why do people fare evade? A global shift in fare evasion research. Transport Reviews-In press (2018)

Else, P.: Optimal pricing and subsidies for scheduled transport services. J. Transp. Econ. Policy 19(3), 263279 (1985)

El-Geneidy, A., Levinson, D., Diab, E., Boisjoly, G., Verbich, D., Loong, C.: The cost of equity: assessing transit accessibility and social disparity using total travel cost. Transp. Res. Part A 91, 302-316 (2016)

Falavigna, C., Hernandez, D.: Assessing inequalities on public transport affordability in two Latin American cities: Montevideo (Uruguay) and Córdoba (Argentina). Transp. Policy 45, 145-155 (2016)

Farber, S., Bartholomew, K., Li, X., Páez, A., Nurul Habib, K.: Assessing social equity in distance based transit fares using a model of travel behavior. Transp. Res. Part A 67, 291-303 (2014)

Fox, J., Weisberg, S.: Nonparametric Regression in R. An Appendix to A R Companion to Applied Regression, Third Edition (2018). Available: https://socialsciences.mcmaster.ca/jfox/Books/Companion/ appendices/Appendix-Nonparametric-Regression.pdf. Accessed 04 Dec 2018 
Friedman, M.: A Theory of the Consumption Function. Princeton University Press, New Jersey (1957)

Gautier, P., Zenou, Y.: Car ownership and the labour market of ethnic minorities. J. Urban Econ. 67(3), 392-403 (2010)

Genter, J.A.: Work beings to drop public transport fares for low income households, 25 May 2019 (2019). Available: https://www.beehive.govt.nz/release/work-begins-drop-public-transport-fares-low-incom e-households. Accessed 20 Jan 2020

Geurs, K., van Wee, B.: Accessibility evaluation of land-use and transport strategies: review and research directions. J. Transp. Geogr. 12(2), 127-140 (2004)

Glaeser, E., Kahn, M., Rappaport, J.: Why do the poor live in cities? The role of public transportation. J. Urban Econ. 63, 1-24 (2008)

Graham, P., Mulley, C.: Public transport pre-pay tickets: understanding passenger choice for different products. Transp. Policy 19, 69-75 (2012)

Gómez-Lobo, A.: Affordability of public transport: a methodological clarification. J. Transp. Econ. Policy 45(3), 437-456 (2011)

Gross, D., Souleles, N.: Do liquidity constraints and interest rates matter for consumer behavior? Evidence from credit card data. Q. J. Econ. 117(1), 149-185 (2002)

Guzman, L., Oviedo, D.: Accessibility, affordability and equity: assessing 'pro-poor' public transport subsidies in Bogotá. Transp. Policy 68, 37-51 (2018)

Harrison, G.W., Lau, M.I., Williams, M.B.: Estimating individual discount rates in Denmark: a field experiment. Am. Econ. Rev. 92, 1606-1617 (2002)

Hickey, R., Lu, A., Reddy, A.: Using quantitative methods in equity and demographic analysis to inform transit fare restructuring decisions. Transp. Res. Rec. 2144, 80-92 (2010)

Isaksson, K.: Lokalsamhället och vardagens transporter-berättelser från Vadstena, Åtvidaberg och Ljura $\mathrm{i}$ Norrköping. Rapport 2010:6. Norrköping: Centrum för kommunstrategiska studier (2010)

Jansson, J.-O.: Marginal cost pricing of scheduled services: a development and generalisation of Turvey and Mohring's Theory of optimal bus fares. J. Transp. Econ. Policy 13, 67-76 (1979)

Jara-Diaz, S., Cruz, D., Casanova, C.: Optimal pricing for travelcards under income and car ownership inequities. Transp. Res. Part A 94, 470-842 (2016)

Jones, P., Lucas, K.: The social consequences of transport decision-making: clarifying concepts, synthesizing knowledge and assessing implications. J. Transp. Geogr. 21, 4-16 (2012)

Ljungberg, A.: Regional kollektivtrafik: några grundläggande välfärdsfrågor. Trafikanalys PM 2013:1. Trafikanalys: Stockholm (2013)

Los Angeles Department of City Planning: Mobility Plan 2035: An Element of the General Plan (2016). Available: https://ladot.lacity.org/sites/g/files/wph266/f/mobilityplnmemo.pdf. Accessed 12 Feb 2019

Lucas, K.: Making the connections between transport disadvantage and social exclusion of low income populations in the Tshwane Region of South Africa. J. Transp. Geogr. 19, 1320-1334 (2011)

Mani, A., Mullainathan, S., Shafir, E., Zhao, J.: Poverty impedes cognitive function. Science 341(6149), 976-980 (2013)

Mayor of London: Mayor's Transport Strategy (2018). Available: https://www.london.gov.uk/sites/default/ files/mayors-transport-strategy-2018.pdf. Accessed 18 Feb 2019

Mohring, H.: Optimisation and scale economies in Urban bus transportation. Am. Econ. Rev. 62, 591-604 (1972)

New York City Department of Transportation: Strategic Plan 2016: Safe-Green-Smart-Equitable (2016). Available: https://www.nycdotplan.nyc/PDF/Strategic-plan-2016.pdf. Accessed 18 Feb 2019

New Zealand Herald: Public transport could become cheaper for Community Service Card holders, 25 May (2019). Available: https://www.nzherald.co.nz/nz/news/article.cfm?c_id=1\&objectid=12234318. Accessed 21 Aug 2019

Parry, I., Small, K.: Should Urban transit subsidies be reduced? Am. Econ. Rev. 99(3), 700-724 (2009)

Parry, I., Timilsina, G.: How should passenger travel in Mexico City be priced? J. Urban Econ. 68(2), 167$182(2010)$

Pissarides, C.: Liquidity considerations in the theory of consumption. Q. J. Econ. 92(2), 279-296 (1978)

Potter, S., Enoch, M., Rye, T., Black, C., Ubbels, B.: Tax treatment of employer commuting support: an international review. Transp. Rev. 26(2), 221-237 (2006)

Preston, J., Rajé, F.: Accessibility, mobility and transport-related social exclusion. J. Transp. Geogr. 15, $151-160$ (2007)

Proost, S., van Dender, K.: Optimal urban transport pricing in the presence of congestion, economies of density and costly public funds. Transp. Res. Part A: Policy Pract. 42(9), 1220-1230 (2008)

Regional Transportation Authority: Regional Transit Strategic plan 2018-2023 (2017). Available: https:// www.rtachicago.org/sites/default/files/documents/strategicprograms/strategicplan/IIT_2018-23_Final/ InvestInTransit_BeginDiscuss_18-23.pdf. Accessed 18 Feb 2019 
SCB: Utvecklingen av tidsbegränsat anställda: Trends for persons in temporary employment. Statistiska meddelanden AM 110 SM 1501 (2015)

SCB: Utgifter för hushåll (0-79 år) (HUT) efter disponibel inkomst och utgiftsslag (Urvalsundersökning.) År 2006-2009 (2017a). Available: http://www.statistikdatabasen.scb.se/pxweb/sv/ssd/START_HE_ HE0201_HE0201A/HUTutgift5/. Accessed 20 Aug .2019

SCB: Att mäta fattigdom (2017b). Available: https:/www.scb.se/hitta-statistik/artiklar/2017/Att-mata-fatti gdom/. Accessed 09 July 2018

SCB: Sammanräknad förvärvsinkomst för boende i Sverige den 31/12 efter kön, ålder, inkomstklass, tabellinnehåll och år (2017c). Available: http://www.statistikdatabasen.scb.se/pxweb/sv/ssd/START_ HE__HE0110_HE0110A/SamForvInk2/table/tableViewLayout1/?rxid=c6181789-4fdf-4409-a5a93b4f9d76575c. Accessed 11 Oct 2018

SCB: Folkmängden efter region, civilstånd, ålder och kön. År 1968-2018 (2019). Available: http://www. statistikdatabasen.scb.se/pxweb/sv/ssd/START_BE_BE0101_BE0101A/BefolkningNy/table/table ViewLayout1/?rxid=632b3538-d9a0-4f54-8cfa-350a861b7de1. Accessed 27 Feb 2019

Scott, D.M., Axhausen, K.W.: Household mobility tool ownership: modeling interactions between cars and season tickets. Transportation 33, 311-328 (2006)

Senate Department for the Environment, Transport and Climate Protection: Berlin Mobility Act (2018). Available: http://gesetze.berlin.de/jportal/portal/t/aqr/page/bsbeprod.psml;jsessionid=8F34446D95E 08CD2C1AF37EE781C4DC8.jp11?pid=Dokumentanzeige\&showdoccase =1\&js_peid =Trefferliste $\&$ documentnumber=1\&numberofresults $=1 \&$ fromdoctodoc $=$ yes $\&$ doc.id=jlr-MobGBErahmen $\&$ doc. part $=X \&$ doc.price $=0.0 \#$ focuspoint. Accessed 18 Feb 2019

Serebrinsky, T., Gómez-Lobo, A., Estupiñán, N., Muñuz-Raskin, R.: Affordability and subsidies in public urban transport: what do we mean, what can be done? Transp. Rev. 29(6), 715-739 (2009)

Simma, A., Axhausen, K.W.: Structures of commitment in mode use: a comparison of Switzerland, Germany and Great Britain. Transp. Policy 8, 279-288 (2001)

Sveriges Riksbank: Sök räntor och valutakurser. Available: https://www.riksbank.se/sv/statistik/sok-ranto r-valutakurser/?g130-SEKEURPMI=on\&from =2015-01-27\&to=2019-02-27\&f=Year\&c=cAver age \&s=Comma. Accessed 27 Feb 2019

The Brookings Institution: From Poverty, Opportunity: Putting the Market to Work for Lower Income Families. The Brookings Institution Metropolitan Policy Program, Washington (2006)

The Economist: It's expensive to be poor: Why low income Americans often have to pay more (2015). Available: https://www.economist.com/united-states/2015/09/03/its-expensive-to-be-poor. Accessed 10 July 2018

Analysis, Transport: Cyklandets utveckling i Sverige 1995-2014 - en analys av de nationella resvaneundersökningarna. Rapport 2015, 14 (2015)

Verbich, D., El-Geneidy, A.: Public transit fare structure and social vulnerability in Montreal, Canada. Transp. Res. Part A 96, 43-53 (2017)

Zeldes, S.: Consumption and liquidity constraints: an empirical investigation. J. Polit. Econ. 97(2), 305-346 (1989)

Publisher's Note Springer Nature remains neutral with regard to jurisdictional claims in published maps and institutional affiliations.

Anders Bondemark is currently a $\mathrm{PhD}$ candidate at The Swedish National Road and Transport Research Institute and Lund University. His research focuses primarily on distributional issues related to the transport sector.

Henrik Andersson is an Associate Professor at Université Toulouse 1 Capitole and researcher at Toulouse School of Economics. His research covers the areas of environmental, health and transport economics.

Anders Wretstrand is an Associate Professor at Lund University, Department of Technology and Society, and a public transport strategist at the regional public transport authority Skånetrafiken. His research covers the areas of transport planning and public transport organization.

Karin Brundell-Freij is a professor (part time, adjunct) at Lund University, affiliated to K2, Swedish National knowledge Center for Public transport. She is also a senior consultant with WSP Sweden. Over the last 30 years she has published papers in a variety of journals on a wide range of issues within the fields of Transport Analysis, Transport Modelling and Transport Policy. 